sciendo Порівняльна професійна педагогіка 9(2)/2019 Comparative Professional Pedagogy 9(2)/2019

DOI: $10.2478 /$ rpp-2019-0017

Undergraduate Student, FARAZ YUSUF KHAN

Integral University, India

Address: Kursi Road, Lucknow, Uttar Pradesh, India

E-mail: Ferez1905@outllook.com

Undergraduate Student, APRAJITA SRIVASTAVA

Integral University, India

Address: Kursi Road, Lucknow, Uttar Pradesh, India E-mail: aprajitasrivastava26@gmail.com

Postgraduate Student, NOMAN AHMAD

Integral University, India

Address: Kursi Road, Lucknow, Uttar Pradesh, India E-mail: nomanah4241@gmail.com

Doctoral Student, SHRISH BAJPAI

Dr. A.P.J. Abdul Kalam Technical University, Address: Sector 11, Jankipuram Vistar, Lucknow, Uttar Pradesh, India E-mail: shrishbajpai@gmail.com

\title{
POWER ENGINEERING EDUCATION IN INDIA: PAST, PRESENT AND FUTURE SCENARIO
}

\begin{abstract}
The present paper deals with the sphere of Power Engineering and it's past developments, current status and future scope of Power Engineering education in India. The aim of this manuscript is to explore the prevalent status of Power Engineering education in India from the grassroot level to Industry level applications, data has been collected from India's premier Institutes of National Importance for this purpose. Introduction to Power Engineering has been given with India-specific past developments and current obstacles faced by the nation's Power Engineering community in order to achieve a hundred percent electrification rate through clean and efficient means. India ranks second on the list of countries with the most population and seventh on the list of countries with the most land area, it is imperative that India becomes independent in terms of energy production, energy transmission and most importantly energy management. Electric power transmission-loss remains a major roadblock in the delivery of sufficient electric power to India's citizens and the Power Engineers of India have to contribute to the best of their abilities in order to solve the problem of electric power transmission-loss in the worlds second most populated and seventh largest country. Challenges faced by Power Engineering aspirants and students who are pursuing undergraduate and postgraduate courses in Power Engineering have been analysed for every level of technical education available for students in India. Requirements for a Power Engineering Undergraduate aspirant currently in twelfth grade or currently pursuing a Diploma degree
\end{abstract}


sciendo Порівняльна професійна педагогіка 9(2)/2019 Comparative Professional Pedagogy 9(2)/2019

and requirements for a Power Engineering Post-Graduate currently in graduation have been explained separately using data from their syllabus which is verified by the All India Council for Technical Education (AICTE), a regulatory body formulated by the Government of India to guide, promote and scrutinize technical education syllabus' in all institutes and organizations of India concerned with science and technology. Since a large portion of India's population resides in rural areas and indulges in agrarian based employment practises, the importance of the Deendayal Upadhyaya Gram Jyoti Yojana (DUGJY) which is an initiative specifically formulated by the Government of India for electrification of India's villages and rural areas has been explained, India is the second most populated country in the world and predominantly most of this population lives in villages , many of which are located in remote areas and thus it becomes nearly impossible to supply continuous electricity to these areas. As mentioned earlier a major part of India's economy depends on agrarian products and by-products, thus it is imperative that Power Engineers of India contribute in the development of these areas through continuous supply of clean electrical power which helps in keeping the rural environments of India's villages clean and green. Government of India's approach towards marginalised sections of the Indian society for the implementations of these schemes so that they can offer last-mile connectivity has been statistically explained. Jawaharlal Nehru National Solar Mission (JNNSM) is being approached and implemented for using the sun as a source of electrical power on war-footing by the Government of India to meet the demands of the second most populated nation on the planet. Power Engineers have actively participated for the efficient utilization of India's 7500-kilometre coastline in order to generate electrical power from the force of blowing wind, employment opportunities for Power Engineering aspirants, Power Engineering Graduate and Power Engineering Postgraduate students have been disclosed in this manuscript. Initiatives of the Government of India in developing and redefining Power Engineering courses through massive open online courses through National Program on Technology Enhanced Learning (NPTEL) which is an online based platform for students and academia alike, NPTEL lectures are available in video format and are delivered by faculties from India's designated Institutes of National Importance. Past involvement of power engineers in the electrification of India and their role in research and development of new technologies such as ultra-high voltage direct current and superconductors has been scrutinized. In conclusion, future scope of Power Engineering and new technological research and developments have been mentioned with regards to Industrial Revolution 4.0. Possibilities of Power Engineering's contribution in research and development of Smart-Grids, Micro-Grids and Electrical Power Management sourced from academia, which includes the fourth largest Ph.D. population on the planet and industry alike have been explored in this manuscript.

Keywords: Power Engineering, Technical Education System, Engineering Education in India.

\section{АНОТАЩЯ}

Дослідження стосується галузі енергетики, ї розвитку, сучасного стану та перспектив розвитку енергетичної освіти у майбутньому. Дані для дослідження були зібрані провідними інститутами національного значення у цій галузі. Актуальність дослідження зумовлена тим фактом, щьо Індія займає друге місие у світі за населенням і сьоме за площею, тому для неї надважливим є отримання незалежності в рамках вироблення енергії, ї̈ передачі та управління. Головною 
sciendo Порівняльна професійна педагогіка 9(2)/2019 Comparative Professional Pedagogy 9(2)/2019

проблемою залишається втрата енергії при передачі ї̈ для населення. У статті подається статистичний аналіз та графічна презентація вищої та пост-вищої освіти у галузі енергетики, описується діяльність інститутів національного значення, у яких така освіта реалізується. Окреслено роль енергетиків у забезпеченні позитивних сочіально-економічних змін. Охарактеризовано діяльність уряду Індії у виробленні, передачі та розповсюдженні енергії, а також перешкоди на цьому шляху. Визначено вклад енергетики як науки у галузь відновлювальної енергії Індії. Проаналізовано проблеми, з якими зіштовхуються студенти та аспіранти, які вивчають енергетику. Вимоги до випускника енергетичної спечіальності обтрунтовано у відповідності з навчальним планом та програмами, затвердженими індійською Радою технічної освіти. Визначено, що енергетик 21 століття повинен мати базові знання механічної інженерії, практичні навички інженера-електрика, далекоглядність комп'ютерного інженера. У статті проаналізовано програму навчання, яка включає всі три галузі інженерії. Наголотено, шзо оскільки Індія $\epsilon$ аграрною країною, енергетична галузь має бути спрямована на забезпечення аграрного сектору чистою електроенергією, зокрема сонячною. Енергетики працюють над ефективним накопиченням та використанням електроенергї з 7500 кілометрової побережної зони 3 використанням енергії вітру. Окреслено можливості працевлаштування аспірантів галузі енергетичної освіти. Охарактеризовано ініціативи уряду Індї щзодо розвитку та удосконалення онлайн освіти у енергетичній галузі. Розкрито фінансові заохочення для аспірантів галузі енергетичної освіти і проиедуру їх отримання.

Проаналізовано сучасний підхід уряду Індї до політики відновлюваної енергії та перспектив ї̈ розвитку у майбутньому.

Ключові слова: енергетика, система технічної освіти, енергетична освіта Індії.

\section{INTRODUCTION}

Power Engineering is regarded as a specialist field Of Electrical Engineering where it encompasses the generation, transmission and usage of electricity and electric power (Ushakov, 2004). Earliest recorded evidence of electricity was found in Greece where Thales of Miletus discovered static electricity while rubbing fur on materials such as amber. Alessandro Volta's invention of the electric battery ushered in a century of electrical and power systems innovation. India's introduction to electricity began in the year 1899 with the establishment of Calcutta Electric Supply Corporation (CESC). Harrison Road in Kolkata became the first electrically illuminated street in the year 1891. Calcutta experienced a transition from horse driven trams and fossil fuel powered industrial motors to electric trams and electric motors for industrial applications. Expertise in Power Engineering was of the upmost importance as work began on the Sidrapong Hydroelectric Power Plant, Shillong which used Beadon Falls as a source of generating electricity. The transmission and distribution component of Power Engineering enabled Shillong to be illuminated by electric lights in the year 1923 (Khan, 2018).

India is the seventh largest country in the world in terms of total surface area and second largest country in the world in terms of population. According to the World Bank, India is the sixth largest economy in the world with $74 \%$ of its populace being classified a literate in accordance with India's Census of 2011 (Khare, 2015). India has taken rapid strides in the field of Power Engineering since its independence in the year 1947. $97 \%$ of India's urban populace has access to electricity, this statistic pales in comparison to $67 \%$ of rural areas having electricity. Generation and transmission of electric power have been 
sciendo Порівняльна професійна педагогіка 9(2)/2019 Comparative Professional Pedagogy 9(2)/2019

subjected to various schemes and policies initiated by the Government of India such as the Deendayal Upadhyaya Gram Jyoti Yojana (DUGJY) which is the successor to the Rajiv Gandhi Grameen Vidyutikaran Yojana (RGGVY). India has made progress in field of Electric Power Generation notwithstanding the fact that it has yet to make the same magnitude of progress in the field of Electric Power Transmission, International Energy Agency and US Energy Information Systems tabled a report stating that India's electricity transmission and distribution losses are as high as $20 \%$ of the electricity intended to be transmitted and distributed (Palit, 2016). To reduce the aforementioned statistic and increase efficiency of India's electric transmission and distribution network, National Load Dispatch Centre under Power System Operation Corporation Limited, a public sector enterprise was tasked with monitoring regional electricity girds, controlling dispatch and monitoring national electricity grids in the year of 2009. By the end of 2013, all of India's Regional Electricity Grids were interconnected and the National Smart Grid Mission was launched by the Government of India to accelerate the growth of better communication systems, decrease transmission and distribution losses, smart meters and other components of an efficient Smart Grid Network. Smart Grid Networks have had the attention of India's best and brightest Power Engineers since the inception of Industrial Revolution 4.0. A Power Engineer of the 21st Century has the responsibility of designing home electrical appliance which is Bureau of Energy Efficiency (BEE) Ratings compliant. BEE Ratings are a 5-point scale for home-based electrical appliances with regards to energy conservation (Kappagantu, 2015).

\section{THE AIM OF THE STUDY}

Our study is aimed at: finding the prevalent status specific to Power Engineering education in India; collecting data related to Power Engineering from various premier institutions of India such as Jadavpur University, National Institutes of Technologies and Indian Institutes of Technologies; overview of Power Engineering Education in India and scope of job opportunities in public sector as well as a private one.

\section{THEORETICAL FRAMEWORK AND RESERCH METHODS}

Scrutiny of engineering education for undergraduate courses and post graduate courses has been done in the past by well-known researchers. This research intends to assimilate information regarding Power Engineering undergraduate courses as well as post graduate courses. Syllabus of Power Engineering has been analyzed from websites of premier technological institutes and institutions classified as Institutes of National Importance. Framework for admissions into Power Engineering courses has been briefly discussed followed by syllabus of Power Engineering undergraduate and post-graduate courses. Doctoral syllabus and responsibilities of a Power Engineering Doctorate holder have been mentioned. Power Engineering is offered in some technological institutes of India to Diploma (Engineering or Technology) students as a compulsory subject. Out of the 4587 engineering and technology-oriented institutions in India, none of them offer a Diploma (Engineering or Technology) degree to students. Jadavpur University, a public university in the state of West Bengal, India offers a Bachelor of Technology degree in Power Engineering to interested students (Power Engineering Department-Jadavpur University, 2019). Admissions into Jadavpur University are done through West Bengal Joint Entrance Examination conducted by the West Bengal Joint Entrance Examinations Board, where students have to perform exceptionally well. First year syllabus of Bachelor of Engineering program for Power Engineering at Jadavpur University consists of subjects regarding advanced and applied sciences, engineering mathematics, engineering drawing 
sciendo Порівняльна професійна педагогіка 9(2)/2019 Comparative Professional Pedagogy 9(2)/2019

with computer aided drafting, and professional communication-oriented subjects. Students perform laboratory experiments as part of their Bachelor of Engineering (Power Engineering) first year course in the field of applied and advanced sciences as well as carpentry, fitting, welding and machining workshops. First year students of Bachelor of Engineering (Power Engineering) are introduced to basic electrical and electrical circuit concepts through subjects named Circuit Theory and Principle of Electrical Engineering, these subjects form the bedrock of complex electrical based theory and laboratory-based subject in the student's subsequent years. Students of Bachelor of Engineering (Power Engineering) indulge in core subjects regarding Power Engineering in their second year, Engineering Thermodynamics is offered to the students divided in two parts, Fluid Mechanics, Materials and Processes, Heat Transfer and Theory of Machines and Design are the subjects offered from Mechanical Engineering background. Subjects from Electrical Engineering domain are also offered such as Electrical Machines in two parts and Power Electronics. Contribution from Electronics Engineering includes Digital Electronics and Basic Electronics. Students perform laboratory experiments in the field of Basic Electrical Engineering, Basic Electronics Engineering and Machining Workshop Practice (Murti, 1972). Information Technology and Consulting is a sector that has found exponential growth in India. Keeping future job prospects from Information Technology and Consulting organizations in mind, Jadavpur University offers a Numerical Methods and Computer Programming subject in which students also have to perform laboratory experiments. All round development of the student is ensured when subjects such as Engineering Economics and Costing are offered to second year students of Bachelor of Engineering (Power Engineering) students. Pre-final year curriculum of Bachelor of Engineering (Power Engineering) is broadly focused on Electric Power Generation with subjects such as Steam Generators, Steam and Gas Turbines, Control Systems, Transducers and Measurement Systems and Microprocessor. Transmission and Distribution skills required by a Power Engineer are provided by Power Transfer Systems, a subject which covers the Mechanical and Electrical aspects of electric power transmission and distribution. Students of pre-final year have to perform laboratory experiments in the field of Transducers and Measurement Systems as well as using MATLAB to solve power plant related numerical problems. India is a signatory to the Paris Climate Change Agreement and the Kyoto Protocol, a congregation of countries who have decided to bring down their green -house gas emissions and slow down global warming. To achieve targets set under the Kyoto Protocol, India must gradually abandon the usage of fossil-fuel based electric power generation plants. Hydro Power Generation and Non-Conventional Power Generation are two subjects offered to pre-final year students of Bachelor of Engineering (Power Engineering) undergraduates in order to equip them with industry relevant knowledge and skills which will help them contribute to solving India's energy problems and saving the environment. Final year syllabus of a Bachelor of Engineering (Power Engineering) student is concerned with 21st century operations, maintenance and optimization of an electricity generating power plant with subjects such as Microcomputer and Digital Systems, Computer Aided Power System Analysis and Power Plant Simulation and Modelling. Undergraduate students of Power Engineering have to complete and submit two projects, one each from Mechanical Engineering domain and Electrical Engineering domain to attain their degree. Students undergoing Bachelor of Engineering (Power Engineering) are recommended a plethora of textbooks to refer from Indian authors and foreign authors alike. First batch of seven Indian Institutes of Technologies and Indian Institute of Science took advantage of India's first 
sciendo Порівняльна професійна педагогіка 9(2)/2019 Comparative Professional Pedagogy 9(2)/2019

telecom revolution in launching the National Program on Technology Enhanced Learning (NPTEL). NPTEL offers courses to students, academia and industry professionals in technological, management and humanities domain. Power Engineering enthusiasts can find Engineering Thermodynamics and Waste to Energy Conversion courses offered by Chemical Engineering Department of Indian Institute of Technology-Kanpur, Electrical Machines offered by Electrical Engineering Department of Indian Institute of TechnologyMadras. Power System Engineering, Fundamental of Power Electronics and Power System Dynamics, Control and Monitoring offered by Department of Electrical Engineering of Indian Institute of Technology, Kharagpur. Additionally, a Power Engineering enthusiast can enhance his or her knowledge by taking up courses regarding Machine Learning and Artificial Intelligence in order to induce inter-disciplinary coursework. To be eligible for a seat in technology and science oriented educational institutes of India, a candidate must have scored 6.0 on a Cumulative Grade Point Average (CGPA) scale of 10 or score a minimum of $60 \%$ in his/her Undergraduate programme along with clearing national-level cut-off Graduate Aptitude Test in Engineering (GATE) conducted by any one of the seven Indian Institutes of Technologies and Indian Institute of Science-Bangalore. Monetary Assistance termed as Institute Assistantship (IA) of Rs.25000 is provided for the first two years which is increased by Rs.3000 for the next two years resulting in IA of Rs.28000. Indian Institute of Technology-Kanpur has crafted an emulation worthy model of Post Graduate studies in the field of Power Engineering, Master of Technology program in Power Engineering (Comprising Power Systems, Power Electronics and High Voltage Engineering) is a two-year program offered by IIT-K (Power Engineering Department, Indian Institute of Technology-Kanpur, 2019). First year syllabus of Master of Technology (Power Engineering) is concerned with Simulation of Modern Power Systems, Electrical Insulation in Power Apparatus and Systems and Basics of Power Electronic Converters, a post graduate student of Master of Technology (Power Engineering) has the freedom to choose a total of six elective subjects in his first year. Second year of Master of Technology (Power Engineering) is concerned with dissertation of the project chosen by the student for which he has to defend his thesis in front of a review board in order to complete his Master of Technology (Power Engineering) degree.

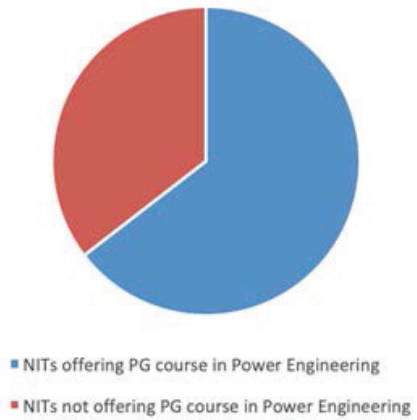

Fig. 1. Availability of Power Engineering Post Graduate Courses in National Institutes of Technologies 
Doctoral students in the field of Power Engineering are involved in development and optimization next generation technologies such as Smart Grids, Superconductors for electric power transmission and distribution, Renewable energy technology, Energy systems and climate change, offshore energy systems, Nuclear energy systems and many more. University Grants Commission-National Eligibility Test (UGC-NET), Council of Scientific \& Industrial Research-National Eligibility Test (CSIR-NET) and Junior Research Fellowship are some examinations that a Power Engineering doctoral aspirant has to clear for admissions to doctoral programs at the institute of their choice. Availability of Power Engineering undergraduate and postgraduate courses in IITs and NITs have been illustrated in Fig. 1 and Fig. 2 respectively.

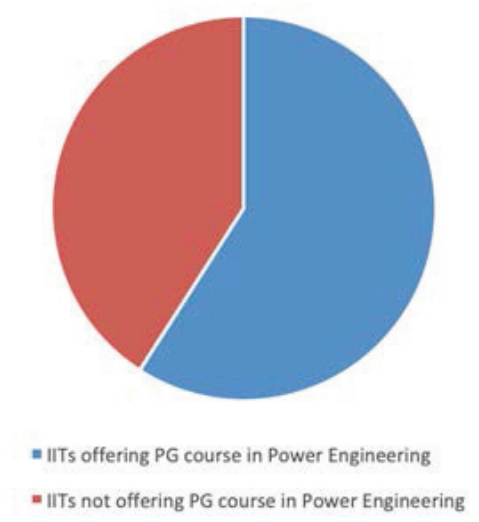

Fig. 2. Availability of Power Engineering Post Graduate Courses in Indian Institutes of Technologies

\section{RESULTS}

Power Engineering graduates and undergraduates have the opportunity to work in the public sector and private sector. Public Sector Undertakings are corporations which are controlled and monitored by the Government of India mainly recruit Power Engineering enthusiasts by the means of Graduate Aptitude Test in Engineering (GATE) examination. Power Engineering have to clear cut-off set by various Public Sector Undertakings followed by an interview, an essential pre-requisite for landing a job in a Public Sector Undertaking is that aspirants must have a minimum of 6.0 out of 10 on the Cumulative Grade Point Average (CGPA) scale or have a minimum of $60 \%$ marks in their graduate degree. Oil and Natural Gas Corporation of India Limited (ONGC), Nuclear Power Corporation of India (NPCIL), National Hydropower Corporation of India (NHPC) and Bharat Heavy Electricals Limited (BHEL) are some Public Sector Undertakings which recruit Power Engineers. Liberalisation of the Indian Economy in 1991 arrived with a boon for the private sector in India. Power generation, transmission and distribution sector benefitted from the opening of the Indian Economy as was seen by the entry of many private sector enterprises in this sector. Tata Power, Adani Power, Reliance Energy are some private sector enterprises which have benefitted the economy of India and its electricity consumers. In order to make India self-dependent in Electrical Power production, the Public Sector and Private Sector has taken up acceleration of Renewable Energy 
sciendo Порівняльна професійна педагогіка 9(2)/2019 Comparative Professional Pedagogy 9(2)/2019

Technologies. The Jawaharlal Nehru National Solar Mission has been implemented by the Government of India to establish India as a global leader in the solar sector by creating the policy norms (Quitzow, 2015). An ambitious target of deploying 20,000 MW of grid connected solar power plant by the year 2022 has been set. The Government of India has even provided subsidy on the installation of solar power plants both off grid and on grid. About $50 \%$ of subsidy is provided to the people of general category, $75 \%$ of subsidy is provided to the people of scheduled caste and $90 \%$ to the people belonging to the category of scheduled tribe. Solar Energy Corporation of India (SECI), a Public Sector Undertaking under the aegis of Ministry of New and Renewable Energy recruits Power Engineers to implement the program objectives of Jawaharlal Nehru National Solar Mission (JNNSM). Tata Solar, Adani Power, Reliance Solar and Suzlon Energy recruit Power Engineers to work in the Renewable Energy Technology domain. Power Engineers are an essential part of utilising India's 7500-kilometre-long coastline in order to generate electrical power sourced from the force of wind and can find employment in Suzlon Energy, a private sector organisation which specializes in generation of electrical power through wind turbines (Khan, 2018).

\section{CONCLUSIONS}

Power Engineers play a crucial role in making India a self-dependent nation in the terms of Electrical Power. Electrification of urban as well as rural areas have been one of the top priorities of Government of India since independence since electrification is responsible for bringing positive socio-economic change in the society. As mention earlier transmission and distribution losses amount to $20 \%$ of the intended supplied electricity in India which is why reducing transmission and distribution losses remains a challenge for Power Engineers of India. Ultra-High Voltage Direct Current (UHVDC) for electric power transmission has emerged as a solution for India's transmission and distribution losses along with Superconductors. Electrical Engineering Department of Indian Institute of Technology-Kanpur has developed emulation worth model of Research and Development in the domain of Power Engineering. Power Management, Smart Grids and Microgrids are some research domains where research scholars work to create next generation technologies. In compliance with India's commitment to Renewable Energy, Power Engineers work on integrating Renewable Energy Systems with conventional source-based energy systems. Onset of Industrial Revolution 4.0 has brought the onus on Power Engineers to deliver environment friendly electric power to manufacturing industries of India and the world. Clean and Renewable Energy domain currently has the best and brightest of Power Engineering minds working to provide environment friendly electrical power to manufacturing units and residential areas alike. Smart Grids with Internet of Things enabled electrical appliances offer real-time statistics for usage of electricity and not only help Power Engineers design better components and electrical appliances but also conserve electrical power.

\section{REFERENCES}

1. Indian Institute of Technology-Kanpur. (2019). Retrieved from https://www.iitk.ac.in/ ee/power-engineering.

2. Jadavpur University. (2019). Retrieved from https:// http://www.jaduniv.edu.in/upload_ files/ course_file/1484121387-1.pdf/.

3. Kappagantu, R., Arul, D. S., \& Venkatesh, M. (2015). Analysis of rooftop solar PV system implementation barrier in Puducherry Smart Grid Pilot Project. Procedia Technology, 21, 490-497. 
4. Khan, F. Y., \& Bajpai, Sh. (2018). Electrical engineering education in India: Past, present \& future. Comparative Professional Pedagogy, 8 (3), 72-81.

5. Khare, S., Bajpai, Sh., \& Bharati, P. K. (2015). Production engineering education in India. Management and Production Engineering Review, 6 (1), 21-25.

6. Khan, F. Y., Khare, S., Srivastava, A. R., Bajpai, S., \& Rasheed, K. (2018, August). A novel design for Highway windmill through re-engineering. The Proceedings of IOP Conference Series: Materials Science and Engineering. Luknow: IOP Publishing.

7. Murti, V. G. (1972). Electrical engineering education in India. IEEE Transactions on Education, 15 (4), 214-219.

8. Palit, D., \& Kaushik, R. B. (2015). Rural electricity access in South Asia: Is grid extension the remedy? A critical review. Renewable and Sustainable Energy Reviews, $60,1505-1515$.

9. Quitzow, R. (2015). Assessing policy strategies for the promotion of environmental technologies: a review of India's National Solar Mission. Research Policy, 44 (1), 233-243.

10. Ushakov, V. Y., (2004). Insulation of high-voltage equipment. Berlin: Springer Science \& Business Media. 